\title{
„Owoce zatrutego drzewa” z perspektywy oskarżyciela publicznego w aspekcie konstytucyjnych podstaw procesu karnego ${ }^{1}$
}

\begin{abstract}
The problems of the so-called poisonous tree in the course of the preliminary legal proceedings appear and continue to appear basically in every individual instance of the evaluation of the body of evidence submitted to the public prosecutor's department. The task of the public prosecutor's department has to do inter alia with the keeping of law and order and the supervision of the prosecution of crime. This task is realised by the supervision of the consistency of the preliminary legal proceedings with the law, and the initialisation and the performance of operational-examination activities by law enforcement organs in the scope of activities which is stipulated in the acts of law which regulate the organisation and the object of activities of these organs. The supervision which was indicated should be realised in an in-depth, comprehensive and substantive manner. Within the framework of the evaluation of the activities engaged by other organs, including those that are authorised to execute and conduct operation-related activities, the public prosecutor is obliged to evaluate the correctness of the process of the accumulation of evidence and the making of decisions in terms of the scope and the means of utilising the said evidence. Such control may and should be conducted with reference to the constitutional principles, described particularly in Art. 2 - the principle of a democratic state of law, Art. 7 - the principle of legalism, Art. 45 Par. 1 - the principle of the right to a trial and the resulting principle of the right to due process. The regulations of the Constitution of the Republic of Poland have not been modified since 1997, therefore with the changed state of the regulations of the Code of Criminal Law (the addition of new regulations in Art. 168 a and b ) or the competence-related acts of law, it is still possible to interpret these regulation in terms of the constitutional norms which were indicated. The new content which was introduced to the code of criminal procedure is a source of serious constitution-related doubts, and the evaluation of the material which was submit-
\end{abstract}

1 Artykuł przedstawia treść referatu wygłoszonego na II Śląskim Forum Karnoprocesowym pt. „Konstytucyjne podstawy procesu karnego” (Katowice, 12 października 2017 r.). 
ted to be treated during criminal proceedings may lead to statements that the very fact of having acquired a piece of evidence with the violation of regulations or by means of a criminal offense and the simultaneous violation of the regulations of the Constitutions is sufficient to preclude the utilisation of a given piece of evidence in these legal proceedings and to preclude the establishment of the actual state of affairs on the basis of such a piece of evidence. It is impossible to accept a situation in which the functionaries of the state, i.e. of public authorities, can collect evidence-related material in violation of the law which is binding and it is in keeping with the law that, on the basis of this material, citizens may bear criminal responsibility.

Key words: Fruit of the poisonous tree, illegally obtained evidence, evidence obtained by means of crime, operation-related activities

\section{Uwagi wstępne. Podstawa i uprawnienie prokuratora do dokonywania oceny pozyskania dowodów}

Problematyka tzw. owoców zatrutego drzewa w toku postępowania przygotowawczego pojawiała się i pojawia w zasadzie przy każdorazowej ocenie materiału dowodowego dostarczanego do prokuratury. Ocenie bowiem każdorazowo należy poddać sposób pozyskania dowodów, a następnie podjąć decyzje w zakresie możliwości ich wykorzystania. Podstawą działania prokuratora $\mathrm{w}$ tym zakresie jest zasada legalizmu wynikająca $\mathrm{z}$ art. 7 Konstytucji RP oraz $\mathrm{z}$ art. 6 EKPC, a więc prawo do rzetelnego procesu.

Zgodnie z przepisami Ustawy o prokuraturze - zarówno tej już nieaktualnej, z dnia 20 czerwca 1985 r., jak i nowej, z dnia 28 stycznia 2016 r. zadaniem prokuratury jest strzeżenie praworządności oraz czuwanie nad ściganiem przestępstw. Zadanie to jest realizowane poprzez nadzór nad zgodnością z prawem postępowania przygotowawczego, a także inicjowania i przeprowadzania czynności operacyjno-rozpoznawczych przez organy ścigania $\mathrm{w}$ zakresie przewidzianym $\mathrm{w}$ ustawach regulujących organizację i przedmiot działania tych organów. Wskazany nadzór winien być realizowany w sposób wnikliwy, pełny i merytoryczny. W ramach oceny działań podejmowanych przez inne organy, w tym także te uprawnione do wykonywania i prowadzenia czynności operacyjnych, prokurator zobowiązany jest do dokonywania oceny prawidłowości sposobu gromadzenia dowodów oraz podejmowania decyzji o zakresie i sposobie ich wykorzystania. W tym także kontekście pojawia się kwestia tzw. owoców zatrutego drzewa, a więc dokonania oceny możliwości wykorzystania dowodów uzyskanych w sposób sprzeczny z prawem, wadliwy formalnie lub merytorycznie. Ocena taka dotyczy oczywiście każdej czynności podejmowanej w toku postępowania przygotowawczego. 


\section{Granice ingerencji w konstytucyjnie gwarantowane prawa i wolności obywatelskie w kontekście „owoców zatrutego drzewa”}

Mając na względzie rozszerzający się zakres stosowania czynności operacyjnych, zdecydowane zmiany podejścia do zagadnienia „owoców zatrutego drzewa" zaczęły pojawiać się w orzeczeniach związanych z czynnościami operacyjnymi. Tam bowiem problem ten w sposób chyba najwyraźniejszy wchodził w zakres norm konstytucyjnych, ponieważ z samego założenia i istoty takich czynności naruszał te normy. Istniała zatem potrzeba określenia granic dopuszczalnej ingerencji aparatu państwowego w prawa i wolności obywatelskie oraz tego, kiedy - w zgodzie z Konstytucją - jest ona możliwa.

W ciągu ostatnich lat w zasadzie można wyróżnić kilka podejść do tego zagadnienia. Pierwszy okres trwał od momentu wejścia w życie przepisów k.p.k. z 1997 r. do 2007 r., kiedy to w jednym ze swych orzeczeń (z dnia 26 kwietnia 2007 r.) SN wyartykułował pojęcie tzw. zgody następczej, a więc potrzeby uzyskania zgody sądu na wykorzystanie materiałów operacyjnych w zakresie szerszym pod względem podmiotowym lub przedmiotowym, niż przewidywała to pierwotna zgoda sądu na wdrożenie czynności operacyjnych ${ }^{2}$. W okresie tym funkcjonował powszechny pogląd o możliwości dowodowego wykorzystania materiałów uzyskanych w toku prowadzonych postępowań. Nikt w zasadzie nie kwestionował możliwości wykorzystania jako dowodów tego wszystkiego, co zdołano w czasie postępowania operacyjnego, np. kontroli telefonicznej, pozyskać. Wspomniane orzeczenie SN, odnoszące się co prawda do materiałów operacyjnych, ale mające znaczenie dla oceny także dowodów uzyskiwanych w normalnym, procesowym trybie, stanowiło wyłom we wskazanej zasadzie. Otóż Sąd stwierdził, że nie ma możliwości wykorzystania dowodowego materiałów w zakresie szerszym, niż uprzednio wyraził na to zgodę sąd, chyba że uzyska się dodatkową, następczą zgodę sądu w tym zakresie. Zgoda taka jednak nigdy nie może dotyczyć czynów nie wskazanych w ustawie - gdy chodzi o takie czyny pozakatalogowe, to wówczas pozyskane materiały nie mogą stanowić podstawy czynienia ustaleń faktycznych. Tym sposobem SN wskazał, że w polskim systemie prawnym zakaz wykorzystania „owoców zatrutego drzewa” jednak funkcjonuje.

Kwestia ta pojawiała się także w orzecznictwie TK, wobec czego analiza oraz ocena materiału dostarczonego do procesu powinna być dokonywana także z uwzględnieniem zasad i wskazań zawartych w orzeczeniach Trybunału Konstytucyjnego. Na szczególną uwagę zasługuje w tym kon-

\footnotetext{
${ }^{2}$ Postanowienie SN z dnia 26 kwietnia 2007 r., I KZP 6/07, OSNKW 2007/5/37.
} 
tekście wyrok TK z dnia 12 grudnia 2005 r. w sprawie K 32/04³. W wyroku tym zostały wskazane konstytucyjne uwarunkowania prawidłowo określonych norm związanych z możliwością realizacji czynności operacyjnych. Tezy tego orzeczenia opisują konstytucyjny wzorzec precyzujący, jakie warunki muszą spełniać normy prawa dotyczące zagadnień pracy operacyjnej. Trybunał Konstytucyjny określił także przesłanki dopuszczalnej ingerencji w sferę praw i wolności, wskazując, iż jest ona dopuszczalna jedynie na podstawie normy prawnej rangi ustawowej dotyczącej zarówno sfery materialnej, jak i procesowej. Zgodnie bowiem z art. 49 Konstytucji RP obywatelom zapewnia się wolność i ochronę tajemnicy komunikowania się. Ograniczenie tych wolności może nastąpić jedynie w przypadkach określonych w ustawie i w sposób w niej określony z zachowaniem zasady proporcjonalności - tzn. wdrażania takich środków i metod, jakie są adekwatne do sytuacji danej sprawy. Jednocześnie stosownie do art. 51 Konstytucji RP nikt nie może być obowiązany inaczej niż na podstawie ustawy do ujawniania informacji dotyczących jego osoby. Władze publiczne nie mogą pozyskiwać, gromadzić i udostępniać innych informacji o obywatelach niż takie, które są niezbędne w demokratycznym państwie prawnym. Każdy ma prawo dostępu do dotyczących go urzędowych dokumentów i zbiorów danych. Ograniczenie tego prawa może nastąpić, ale określić je może tylko ustawa. Każdy ma prawo do żądania sprostowania oraz usunięcia informacji nieprawdziwych, niepełnych lub zebranych w sposób sprzeczny z ustawą. Zasady i tryb gromadzenia oraz udostępniania informacji określać może tylko ustawa.

Nadto podstawową cechą ingerencji $\mathrm{w}$ tak zakreślone prawa gwarantowane Konstytucją bezwarunkowo musi być przestrzegana zasada subsydiarności, oznaczająca, iż jest ona dopuszczalna jedynie wówczas, gdy inne działania okazały się nieskuteczne przy jednocześnie precyzyjnie określonym celu takiej ingerencji. Tezy zawarte we wskazanym wyroku dotyczą wszystkich czynności operacyjnych. Na podkreślenie w tym miejscu zasługuje także stwierdzenie, iż przepisy związane z ingerencją w konstytucyjnie chronione prawa i wolności muszą być określane precyzyjnie, a ich interpretacja nie może być rozszerzana.

\section{Wykorzystanie materiału operacyjnego w procesie karnym}

Kształtująca się w opisany powyżej sposób linia orzecznicza doprowadziła do przyjęcia, zarówno w ustawach kompetencyjnych poszczegól-

${ }^{3}$ Wyrok TK z dnia 12 grudnia 2005 r., K 32/04, OTK-A 2005/11/132, Dz.U. 2005, nr 250, poz. 2116. 
nych służb uprawnionych do prowadzenia czynności operacyjnych, jak i w przepisach dotyczaccych bezpośrednio uprawnień prokuratora, przepisów opisujących zasady pozyskiwania zgód następczych oraz wykorzystywania materiału operacyjnego w procesie karnym, a także na bazie tych przepisów wywiedziono swoiste zakazy dowodowe dotyczące „owoców zatrutego drzewa". Doszło do tego w roku $2011^{4}$.

W coraz większym zakresie orzecznictwo stopniowo wyrażało zdecydowane poglądy dotyczace tej kwestii. Stosownie na przykład do postanowienia Sądu Najwyższego z dnia 30 listopada 2010 r. w sprawie III K $152 / 10^{5}$ niezachowanie przesłanek określonych w ówczesnym art. 19a Ustawy o Policji - kontrolowane wręczenie korzyści majątkowej, uniemożliwia w procesie karnym wykorzystanie uzyskanego w tym trybie materiału dowodowego. W tym przypadku, zgodnie z ww. artykułem, wręczenie kontrolowane było realizowane w celu „sprawdzenia uzyskanych wcześniej wiarygodnych informacji o przestępstwie”. W toku postępowania będącego wówczas w rozpoznaniu nie ustalono, czy funkcjonariusze policji posiadali wcześniej jakiekolwiek informacje o przyjmowaniu korzyści majątkowych przez osobę, wobec której zastosowano czynności kontrolowanego wręczenia korzyści majątkowej.

Mając na względzie zatem konsekwencje wskazane w cytowanym orzeczeniu, istnieje konieczność każdorazowego badania przesłanek zasadności stosowania w danej sytuacji konkretnego instrumentu i metody pracy operacyjnej, zwłaszcza tzw. przesłanek ogólnych zamieszczanych we wstępnej części przepisu. Tak należy postępować względem nie tylko instytucji opisanych w ustawie o Policji, ale wobec wszystkich przewidzianych w aktach prawnych, dotyczących również innych służb.

Dokonując zgodnie z powyższymi zasadami analizy treści i jakości przedkładanego prokuratorowi materiału, stosownie do tezy wskazanego postanowienia Sądu Najwyższego, niezachowanie przesłanek określonych w ustawach kompetencyjnych uniemożliwiało w procesie karnym wykorzystanie uzyskanego w tym trybie materiału dowodowego. Stwierdzić wówczas należało, iż np. wykreowane przez daną służbę zdarzenie nie może być w ogóle dowodzone innymi sposobami (materiałem uzyskanym w toku dalszych czynności operacyjnych, dowodowych, w tym ze-

${ }^{4}$ Ustawa z dnia 4 lutego 2011 r. o zmianie ustawy Kodeks postępowania karnego, Dz.U. 2011, nr 53, poz. 273, którą dokonano zmian ustaw o: Policji, Centralnym Biurze Antykorupcyjnym, Straży Granicznej, Kontroli Skarbowej, Agencji Bezpieczeństwa Wewnętrznego oraz Agencji Wywiadu, Prokuraturze, Służbie Kontrwywiadu Wojskowego oraz Służbie Wywiadu Wojskowego, Żandarmerii Wojskowej i wojskowych organach porządkowych.

${ }^{5}$ Postanowienie SN z dnia 30 listopada 2010 r., sygn. III K 152/10, OSNKW 2011, z. 1, poz. 8; OSP 2011, z. 6, poz. 65 . 
znaniami świadków) - stanowiło bowiem „zatrute drzewo”, a nie jedynie jego „owoc” i złamanie tej zasady stanowiłoby dowodzenie zaistnienia przestępstwa wykreowanego przez służbę w sposób niezgodny z normami ustawowymi.

Zasadnie w tym kontekście pojawiało się pytanie, czy pierwotnie „skażony" materiał, uzyskany w sposób sprzeczny z ustawą, na podstawie np. niezasadnie uzyskanego postanowienia uprawnionego organu, może stanowić podstawę kolejno wdrażanych, następnych czynności operacyjnych. Innymi słowy, czy pierwotne „skażenie” pociąga za sobą nielegalność tylko czynności operacyjnych realizowanych w oparciu o takie niezasadnie uzyskane postanowienie, czy też dotyczy także każdej następnej czynności operacyjnej w tej samej sprawie operacyjnego rozpracowania $\mathrm{i} \mathrm{w}$ sprawach uruchamianych na podstawie informacji $\mathrm{w}$ jej toku pozyskanych. Dotychczasowa skuteczność dowodowa „owoców zatrutego drzewa" w postępowaniu karnym została bowiem poddana w wątpliwość w orzecznictwie sądowym, w szczególności w odniesieniu do materiałów operacyjnych, co znajduje uzasadnienie w treści art. 51 ust. 4 Konstytucji $\mathrm{RP}$ - np. wyrok SA w Białymstoku z dnia 18 marca 2010 r., sygn. II AKa $18 / 10^{6}$. Zgodnie z tym orzeczeniem wartości chronione przez art. 5 i art. 7 Konstytucji (ochrona wolności i praw człowieka i obywatela oraz zasada Państwa Prawnego), a w szczególności nałożone przez ustawę zasadniczą $\mathrm{w}$ art. 9 zobowiązanie, że Rzeczpospolita Polska przestrzega wiążącego ją prawa międzynarodowego, czyni niedopuszczalnym wykorzystywanie przez organy państwowe - pod jakąkolwiek postacią oraz w jakiejkolwiek formie i celu - informacji o obywatelach, które są pozbawione atrybutu legalności. Gwarancją przestrzegania tych wartości jest zakaz wykorzystywania takiej wiedzy, nawet w sposób pośredni, do późniejszej procesowej jej legalizacji. W cytowanym orzeczeniu podkreślono, że „żadne Państwo aspirujące do miana demokratycznego i praworządnego na takie postępowanie pozwolić sobie nie może. Usankcjonowanie takiego działania organów państwowych nie ma nic wspólnego z zasadami legalizmu, prowadząc do swoistej schizofrenii realizowanych w imieniu tego państwa wartości. Dając możliwość wykorzystywania w sposób nieograniczony rezultatów działań operacyjnych, również tych nielegalnych, włączając je okrężną drogą w materiał procesowy, legalizowałoby się de facto bezprawne działania organów państwa $\mathrm{w}$ imię walki z przestępczością, a obrazując dosadniej - otwierałoby ścieżkę do stosowania podsłuchów »totalnych «, gromadzenia w ten sposób wszystkich możliwych informacji o obywatelach, by następnie - pod pozorem le-

${ }^{6}$ Wyrok SA w Białymstoku z dnia 18 marca 2010 r., sygn. II AKa 18/10, OSAB 2010, z. 1, s. 32-39. 
galności - przekształcać tę wiedzę na materiał procesowy, służący do walki z przestępczością. Takie działanie nie miałoby nic wspólnego ze standardami cywilizowanego państwa, stanowiąc niebywałe pole do nadużyć, charakteryzujących systemy totalitarne"7.

Kierując się wskazanymi argumentami, można było stwierdzić na gruncie obowiązujących poprzednio przepisów, że pierwotnie - sprzecznie z ustawą - uzyskana np. zgoda na wykonywanie czynności w określonym trybie ustawy kompetencyjnej, np. o Policji, o CBA, o ABW itp., przekreślała także każdą następną czynność operacyjną w tej samej sprawie operacyjnego rozpracowania i w sprawach uruchamianych na podstawie informacji $\mathrm{w}$ jej toku pozyskanych. Takiego materiału nie można było wykorzystać jako dowodów w toku prowadzonego postępowania karnego.

Jako niedopuszczalne jawi się także stanowisko dotyczące tego, że naruszenie konstytucyjnych zasad swobody komunikowania się i tajemnicy korespondencji może wynikać z rozporządzeń wykonawczych. Dopuszczenie takiej możliwości nie jest uprawnione w świetle raczej powszechnie aprobowanej wyjątkowości w sferze naruszeń konstytucyjnych swobód obywatelskich, które muszą wynikać z ustaw, a nie z aktów niższego rzędu. Przepisy rozporządzeń wykonawczych bowiem - niezależnie od ich brzmienia - będąc przepisami pozaustawowymi, nie mogą stanowić samodzielnej podstawy stosowania niejawnej rejestracji czynności, ingerującej w konstytucyjnie chronione prawo do prywatności i do tajemnicy komunikowania się.

Mając na względzie przedstawione powyżej argumenty, można było twierdzić, iż z powodu różnych uchybień prokuratura w wielu wypadkach nie otrzymywała materiału z czynności operacyjnych realizowanych przez poszczególne służby, który mógłby być dowodowo wykorzystany w postępowaniu karnym, a okoliczności, jakie w wyniku stosowania czynności operacyjnych zostały przez te służby ustalone, nie mogły być dowodzone jakimikolwiek innymi czynnościami procesowymi. Skoro bowiem czynności operacyjne pozbawione były podstaw prawnych i prowadzono je w sposób sprzeczny z ustawą, to nie można było dowodzić nieprawidłowo wykreowanej sytuacji innymi środkami. Takie postępowanie stanowiłoby bowiem obejście norm procesowych i jednocześnie naruszało wskazane normy konstytucyjne.

Prezentowane argumenty, ukształtowane już wówczas orzecznictwo i powszechne przekonanie o potrzebie precyzyjnego, normatywnego określenia zasad procesowych, a w szczególności dowodowych, doprowadziły do regulacji, jaka pojawiła się w Kodeksie postępowania karnego

${ }^{7}$ Jak w przyp. 5. 
w art. 168a, wprowadzonego nowelą z dnia 27 września 2013 r. ${ }^{8}$. Przepis ten brzmiał: „niedopuszczalne jest przeprowadzenie i wykorzystanie dowodu uzyskanego do celów postępowania karnego za pomocą czynu zabronionego, o którym mowa w art. $1 \S 1$ kk". Norma ta obowiązywała od 1 lipca 2015 r., lecz nie zdążyła się utrwalić i nie pozyskano na jej bazie reprezentatywnego orzecznictwa, bowiem przepis ten zmieniono kolejną nowelą kodeksu9', która zaczęła obowiązywać od 15 kwietnia 2016 r. Przepis z 2013 r. był procesową podstawą funkcjonowania zakazu wykorzystywania w procesie karnym „owoców zatrutego drzewa” i to zakazem dotyczącym wszystkich, nie tylko operacyjnych, czynności, który w ramach kontradyktoryjnego procesu dotyczył obu jego stron. Norma ta miała swe oparcie zarówno bezpośrednio w przepisach konstytucyjnych, jak i w orzecznictwie TK i SN oraz licznych już w tamtym czasie orzeczeniach sądów powszechnych.

\section{Nowe regulacje prawne (art. 168a i 168b k.p.k.) a zasady konstytucyjne}

Nowela przepisów postępowania karnego z roku 2016 zmieniła powyższy stan i w polskim prawie procesowym nastąpił kolejny okres normatywny. Ten nowy stan - obecnie obowiązujący - odwraca wskazaną zasadę, nawiązując do stanu sprzed orzeczenia SN z 2007 r., stając w kontrze do orzecznictwa TK. Wracamy bowiem do stanu, w którym zakaz wykorzystania „owoców zatrutego drzewa” przestaje obowiązywać. Tak przynajmniej wydaje się na podstawie analizy nowych przepisów. Ustawodawca świadomy orzecznictwa i stanowiska doktryny przyjął przepisy mające $\mathrm{w}$ jego zamiarze dopuścić dowody niepełne, obarczone wadami.

W tym kontekście na pierwszy plan wysuwają się nowe przepisy art. 168 a i 168 b.

$\mathrm{Z}$ art. 168b wynika, że jeżeli na skutek kontroli operacyjnej zarządzonej na wniosek uprawnionego organu na podstawie przepisów szczególnych uzyskano dowód popełnienia przez osobę, wobec której kontrola operacyjna była stosowana, innego niż przestępstwo objęte zarządzeniem kontroli operacyjnej przestępstwa ściganego $\mathrm{z}$ urzędu lub przestępstwa skarbowego bądź przestępstwa ściganego z urzędu lub przestępstwa skarbowego popełnionego przez inną osobę niż objęta zarządzeniem kontroli

\footnotetext{
${ }^{8}$ Ustawa z dnia 27 września 2013 r. o zmianie ustawy Kodeks postępowania karnego oraz niektórych innych ustaw, Dz.U. 2013, poz. 1247.

${ }^{9}$ Ustawa z dnia 11 marca 2016 r. o zmianie ustawy Kodeks postępowania karnego oraz niektórych innych ustaw, Dz.U. 2016, poz. 437.
} 
operacyjnej, prokurator podejmuje decyzję w przedmiocie wykorzystania tego dowodu w postępowaniu karnym.

W zestawieniu z poprzednim stanem prawnym stwierdzić należy, że:

1) zmienił się organ procesowy wydający decyzję w przedmiocie tzw. zgody następczej - dotychczas był to zawsze sąd, a obecnie jest nim prokurator;

2) odstąpiono od sformułowanego wprost w przepisie wymogu, zgodnie z którym zgodą następczą mogą być objęte wyłącznie przestępstwa katalogowe - dotychczas zgoda ta mogła dotyczyć wyłącznie czynów enumeratywnie wymienionych w zamkniętych katalogach ujętych w przepisach kompetencyjnych;

3) zrezygnowano z określenia terminu na podjęcie decyzji o wykorzystaniu materiałów z kontroli operacyjnej - poprzednio procedura ta, w tym i terminy takie, były w ustawie określone.

$\mathrm{Na}$ gruncie tej nowej regulacji pojawiły się wątpliwości konstytucyjne. Po pierwsze wskazuje się, że przeniesienie kompetencji do podjęcia decyzji w zakresie zgody następczej na prokuratora narusza zasadę konstytucyjnego prawa do sądu. Po drugie dochodzi do sprzeczności sprowadzającej się do tego, że pierwotną zgodę wydaje sąd, a następczą, w zakresie czy to rozszerzenia przedmiotowego, czy też podmiotowego, podejmuje organ niesądowy - prokurator. Dochodzi więc do niezrozumiałej sytuacji, gdy pierwotna ingerencja w prawa i wolności obywatelskie dokonywana jest za pośrednictwem sądu, a w sytuacji, gdy w toku stosowanej inwigilacji w jej zasięgu pojawi się nowa osoba, decyzji nie podejmuje już sąd, lecz prokurator. Pojawia się zatem, stawiane zasadnie w tym kontekście, pytanie, czym od siebie różnią się te dwie osoby, że w stosunku do pierwszej wymóg sądowej zgody jest bezwzględnym warunkiem ingerencji w jej prawa, a w stosunku do drugiej warunku takiego nie ma.

Sygnalizowany brak określenia terminu podjęcia decyzji w przedmiocie zgody następczej nie stanowi newralgicznego problemu, bowiem wskazanie organu uprawnionego do podjęcia takiej decyzji limitowane jest władztwem tego organu nad przedmiotem postępowania. Skoro decyzję ma podejmować prokurator, to termin ten limitują poszczególne decyzje podejmowane w czasie trwania postępowania przygotowawczego (np. wszczęcie postępowania, przedstawienie zarzutów, ich zmiana). Wydaje się bezsprzeczne, że tylko w czasie trwania postępowania przygotowawczego prokurator ma możliwość i uprawnienie do podjęcia decyzji w tym przedmiocie. Zaznaczyć natomiast należy, że brak wskazania terminu na podjęcie takiej decyzji będzie miało swe konsekwencje, gdy spojrzy się na wymóg niszczenia materiałów nieprzydatnych w danym postępowaniu. Należy zwrócić uwagę, że gdy takie materiały nie zostaną zniszczone, bo nie ma wskazanego terminu, w jakim winno to nastąpić, 
i będą przechowywane przez jakiś czas (rok, dwa, a może 5 lat), po czym wróci się do nich, bo pojawiła się jakaś nowa sprawa, do której materiały te będą wykorzystywane - to zaktualizuje się pytanie, czy taka sytuacja czyni, czy nie, zadość warunkom konstytucyjnym i zasadom wykorzystania w ten sposób tych materiałów jako dowodów. W gruncie rzeczy bowiem materiały te były bezprawnie przechowywane, a zatem czy można je wykorzystać? Zasadna wydaje się odpowiedź negatywna, bo właśnie bezprawnie je przechowywano i nie dopełniono wymogu ich zniszczenia.

Poważne zastrzeżenia budzi rezygnacja przez ustawodawcę z uzależnienia możliwości wykorzystania materiałów z kontroli operacyjnej od tego, czy dotyczą one przestępstwa katalogowego. Zanim zgoda następcza pojawiła się jako norma prawna w roku 2011, wyprowadzano ją z norm gwarancyjnych. Tak było m.in. we wspomnianym wcześniej orzeczeniu SN z 2007 r. Trybunał Konstytucyjny natomiast w swych orzeczeniach (np. z dnia 30 lipca 2014 r. $^{10}$ ) jednoznacznie wskazywał, że ustawodawca, wprowadzając do systemu instytucje kontroli operacyjnej, zobowiązany jest zdefiniować zamknięty i możliwie wąski katalog poważnych przestępstw uzasadniających tego rodzaju ingerencje w status jednostki. Wypada się zgodzić m.in. ze Zbigniewem Niemczykiem, Prokuratorem Prokuratury Regionalnej w Gdańsku, który w swej publikacji „Nowy kształt kontroli operacyjnej po zmianach ustawy o Policji i Kodeksu postępowania karnego"11 wskazał, iż problem ten stanowi najpoważniejszą wątpliwość zgodności ustawy z normami konstytucyjnymi. Podzielam jego pogląd, że rezygnacja $\mathrm{z}$ odniesienia do zamkniętego katalogu przestępstw z ustaw kompetencyjnych takie wątpliwości wywołuje, w szczególności gdy odniesiemy się do orzecznictwa TK oraz ETPC. Należy pamiętać o tym, że TK wymagał zdefiniowanego zamkniętego katalogu i możliwie wąskiego katalogu poważnych przestępstw uzasadniających ingerencje $\mathrm{w}$ prawa i wolności obywatelskie. ETPC ${ }^{12}$ natomiast wskazywał, że minimalnym standardem konwencyjnym jest określenie w prawie przestępstw, w odniesieniu do których organy państwa mogą pozyskiwać niejawnie informacje o osobach i nie jest tu wystarczające stwierdzenie, że ma to dotyczyć tzw. poważnych przestępstw, nawet gdy pojęcie to jest zdefiniowane w ustawie. Sąd Najwyższy także poświęcił temu tematowi kilka swych orzeczeń. Na uwagę zasługuje szczególnie to z dnia 26 kwiet-

${ }_{10}$ Wyrok TK z dnia 30 lipca 2014 r., sygn. K 23/14, OTK-A 2014, nr 7, poz. 80, Dz.U. 2014, poz. 1055.

${ }^{11}$ Z. NIEMCZYK: Nowy ksztatt kontroli operacyjnej po zmianach ustawy o Policji i Kodeksu postępowania karnego. „Kwartalnik Krajowej Szkoły Sądownictwa i Prokuratury” 2017, z. 2 (26).

${ }^{12} \mathrm{~Np}$. wyrok ETPC z dnia 24 kwietnia 1990 r. w sprawie Kruslin p. Francji; wyrok ETPC z dnia 25 września 2001 r. w sprawie P.G. i J.H. p. Wielkiej Brytanii (skarga nr 44787/98). 
nia 2007 r. $^{13}$, bowiem Sąd jednoznacznie wskazał, że dowody uzyskane w wyniku czynności operacyjnych policji opisanych w art. 19 ustawy o Policji to dowody dotyczące wyłącznie tych przestępstw, które opisane są w art. 19 ust. 1 tejże ustawy, a więc tych z zamkniętego katalogu. Sąd wskazał, że uzyskane w ramach kontroli operacyjnej materiały stanowiące dowody popełnienia przestępstw innych niż wymienione bezpośrednio $\mathrm{w}$ tym przepisie gromadzone są $\mathrm{w}$ sposób sprzeczny z prawem, bowiem niedopuszczalne jest domniemanie, że zgoda sądu na konkretną kontrolę operacyjną legalizuje gromadzenie wszelkich informacji w jej ramach. Sąd wykluczył możliwość wykorzystania takich materiałów. Ten kierunek interpretacji znalazł szerokie poparcie w judykaturze i licznych już publikacjach z tego tematu.

Dopiero nowela kodeksu postępowania karnego z 2016 r. staje w kontrze do tak prezentowanego stanowiska. Nową treścią jest także to, co zawiera w sobie art. 168a k.p.k., dotyczący kwestii wykorzystania obarczonego wadą materiału. Zgodnie $\mathrm{z}$ tym przepisem dowodu nie można uznać za niedopuszczalny wyłącznie na tej podstawie, że został uzyskany z naruszeniem przepisów postępowania lub za pomocą czynu zabronionego, o którym mowa w art. 1 § 1 Kodeksu karnego, chyba że dowód został uzyskany w związku z pełnieniem przez funkcjonariusza publicznego obowiązków służbowych w wyniku: zabójstwa, umyślnego spowodowania uszczerbku na zdrowiu lub pozbawienia wolności. Rodzaj naruszeń oczywiście może być różny - od kwestii dotyczących niewłaściwej formy decyzji procesowej, po wykorzystywanie materiałów z nielegalnej kontroli operacyjnej. Skutki tych naruszeń również będą różne. Jeśli w przypadku wyrażenia woli w błędnej formie (zamiast $\mathrm{w}$ formie postanowienia w zarządzeniu o wykorzystaniu materiałów operacyjnych) można nie wyciągać konsekwencji w postaci sfalsyfikowania tak wprowadzonego do procesu materiału, to już w przypadku materiałów z nielegalnej operacji sytuacja będzie diametralnie inna. W takiej sytuacji należy stwierdzić, że „nielegalność to realizacja czynności przez podmiot nieuprawniony albo przez uprawniony, lecz w sposób sprzeczny z ustawą. Jeśli kontrola operacyjna dotknięta będzie którąś z takich wad, to nie zostanie zrealizowany wymóg z art. 168b k.p.k., bowiem nie będzie można uznać, że kontrola taka została zarządzona na wniosek uprawnionego organu na podstawie przepisów szczególnych i tym samym nie będzie można wykorzystać uzyskanych w wyniku takiej kontroli materiałów - dowodów"14. Stanowisko takie wyraził już wspomniany przeze mnie Prokurator Z. Niemczyk i zgadzam się z nim. Tak przedstawiona interpretacja ma swe umocowanie

\footnotetext{
${ }^{13}$ Jak w przyp. 1.

${ }^{14}$ Jak w przyp. 10.
} 
w Konstytucji RP oraz w art. 6 ust. 1 EKPC, a więc prawie do rzetelnego procesu. Nowa redakcja przepisu art. 168a k.p.k. mówi wyłącznie o tym, że nie można uznać za niedopuszczalny dowodu uzyskanego z naruszeniem odpowiednich przepisów wyłącznie na tej podstawie prawnej, co nie oznacza niemożności powoływania się na nią w ogóle. Należy pamiętać tutaj o orzecznictwie sprzed 1 lipca 2015 r. w zakresie zakazów wykorzystania dowodów uzyskanych niezgodnie z prawem, uregulowaniach konwencyjnych i orzeczeniach ETPC. Już w wymienionym wcześniej judykacie z dnia 30 listopada 2010 r. SN wskazał skutki niezachowania ustawowych warunków dopuszczalności przeprowadzenia czynności operacyjno-rozpoznawczych, stwierdzając, że w takiej sytuacji nie ma możliwości wykorzystania tak zdobytych materiałów w procesie karnym. Jednocześnie sąd stwierdził, że nie jest możliwe zaakceptowanie stanu, w którym funkcjonariusze państwa, a więc władzy publicznej, mogliby gromadzić materiał dowodowy wbrew obowiązującemu prawu, a zgodnie z prawem, na podstawie tego materiału, obywatele mogli ponosić odpowiedzialność karną ${ }^{15}$.

W tym aspekcie, celem systemowego ujęcia woli ustawodawcy, mając na uwadze treść omawianych przepisów art. 168a i 168b k.p.k., wskazać wypada jeszcze jeden przepis, tym razem $\mathrm{z}$ ustawy o prokuraturze z 2016 r., a mianowicie art. 137 \$ $2^{16}$. Zgodnie z nim nie stanowi przewinienia dyscyplinarnego prokuratora jego działanie lub zaniechanie podjęte wyłącznie $\mathrm{w}$ interesie społecznym. Interpretacje tej normy w kontekście przedstawionych rozważań pozostawiam czytelnikowi.

\section{Prokonstytucyjna możliwość wykładni przepisów w zakresie oceny sposobu pozyskania dowodów do procesu karnego}

Tezy, które zostały powołane w zaprezentowanych orzeczeniach SN, są aktualne i mają swe oparcie w Konstytucji RP, a w szczególności w jej art. 2 - zasada demokratycznego państwa prawnego, art. 7 - zasada legalizmu, art. 45 ust. 1 - zasada prawa do sądu i wynikająca z niej zasada prawa do rzetelnego procesu. W tym miejscu wypada podkreślić, że przepisy Konstytucji od 1997 r. nie zostały zmienione, zatem przy zmienionym stanie przepisów k.p.k. czy też ustaw kompetencyjnych w dalszym ciągu możliwa jest wykładnia tych przepisów przez pryzmat wskazanych norm konstytucyjnych. Jako przykład takiego postępowania przywołuję Wyrok

\footnotetext{
${ }^{15}$ Jak w przyp. 4.

${ }^{16}$ Ustawa z dnia 28 stycznia 2016 r. o prokuraturze, T.j. Dz.U. 2017, poz. 1767.
} 
SA we Wrocławiu z dnia 27 kwietnia 2017r., sygn. II AKa 213/16 ${ }^{17}$. Sąd ten stwierdził, że: „Skoro ustawa z 2006 r. o CBA odnośnie kontroli operacyjnej wymaga, już we wniosku do sądu o jej zastosowanie, wskazania zarówno osoby, której ma ona dotyczyć, jak i czynu lub czynów, odnośnie których kontrola ta ma być zastosowana, to jedynie w takim właśnie podmiotowym i przedmiotowym zakresie, określonym w postanowieniu sądu o zarządzeniu tej kontroli, kontrola operacyjna staje się dopuszczalnym, legalnym wkroczeniem w sferę wolności. Dowody pozyskane wprawdzie w ramach zarządzonej przez sąd kontroli, ale poza jej granicami, a więc niezgodnie z wymogami ustawy, nie są dowodami uzyskanymi legalnie. Przed 1 lipca 2015 r. nie obowiązywały w procedurze karnej żadne szczególne unormowania nawiązujące do treści art. 168a k.p.k. Dowód może zostać uznany za niedopuszczalny, jeżeli został uzyskany z naruszeniem przepisów postępowania lub za pomocą czynu zabronionego przy jednoczesnym naruszeniu przepisów Konstytucji RP (np. jej art. 30, 47, 49 czy 51). W takiej sytuacji ograniczenie ustawowe wyrażone zwrotem »wyłącznie na tej podstawie, że został uzyskany z naruszeniem przepisów postępowania lub za pomocą czynu zabronionego « (art. 168a k.p.k.) nie ma zastosowania”.

Innymi słowy sąd, już pod rządami nowego brzmienia przepisów k.p.k., dokonał oceny przedłożonego do procesu karnego materiału, stwierdzając, że sam fakt pozyskania dowodu z naruszeniem przepisów lub za pomocą czynu zabronionego i naruszenia przepisów Konstytucji jest wystarczajacy do tego, by dany dowód nie mógł być w tym procesie wykorzystany oraz by na jego podstawie możliwe było czynienie ustaleń faktycznych.

\section{Podsumowanie}

Jak zatem zasygnalizowano, kwestia tzw. owoców zatrutego drzewa oraz tego, czy, w jakim zakresie i kiedy funkcjonuje ich zakaz jest ,wiecznie żywa" i nie wykuło się jeszcze ostateczne, utrwalone i bezsporne stanowisko ani judykatury, ani doktryny. W tej sytuacji podejmowanie prób interpretacji aktualnych przepisów oraz jej kierunków jest w rękach każdego prawnika zajmującego się tą materią.

17 Wyrok SA we Wrocławiu z dnia 27 kwietnia 2017 r., sygn. II AKa 213/16, OSA 2017, z. 4-3, poz. 63. 


\section{Bibliografia}

\section{Literatura}

Z. NIEMCZYK: Nowy kształt kontroli operacyjnej po zmianach ustawy o Policji i Kodeksu postępowania karnego. „Kwartalnik Krajowej Szkoły Sądownictwa i Prokuratury" 2017, z. 2 (26).

\section{Orzecznictwo}

Wyrok TK z dnia 12 grudnia 2005 r., K 32/04, OTK-A 2005, z. 11, poz. 132.

Wyrok TK z dnia 30 lipca 2014 r., K 23/14, OTK-A 2014, z. 7, poz. 80.

Postanowienie SN z dnia 26 kwietnia 2007 r., I KZP 6/07, OSNKW 2007, z. 5 , poz. 37.

Postanowienie SN z dnia 30 listopada 2010 r., III K 152/10, OSNKW 2011, z. 1, poz. 8; OSP 2011, z. 6, poz. 65.

Wyrok SA w Białymstoku z dnia 18 marca 2010 r., II AKa 18/10, OSAB 2010, z. 1, poz. 32-39.

Wyrok SA we Wrocławiu z dnia 27 kwietnia 2017 r., II AKa 213/16, OSA 2017, z. 4, poz. 3-63.

Wyrok ETPC z dnia 24 kwietnia 1990 r. w sprawie Kruslin p. Francji.

Wyrok ETPC z dnia 25 września 2001 r. w sprawie P.G. i J.H. p. Wielkiej Brytanii, skarga nr 44787/98. 